\title{
PENINGKATAN MOTIVASI IBU RUMAH TANGGA UNTUK MEMANFAATKAN TANAMAN OBAT KELUARGA (TOGA)
}

\author{
Y. Kusumawaty ${ }^{1}$ dan S. Khaswarina ${ }^{2}$
}

\begin{abstract}
ABSTRAK
Kecenderungan masyarakat untuk kembali ke alam (back to nature) telah meningkatkan minat terhadap obat herbal. Kondisi ini membuka peluang bisnis aneka tanaman obat termasuk usaha budidaya tanaman obat keluarga (TOGA). Tujuan kegiatan adalah meningkatkan motivasi masyarakat untuk memanfaatkan peluang bisnis tanaman herbal secara kolektif. Kegiatan dilaksanakan dalam tiga tahap, yaitu: (1) pendekatan masalah yang dihadapi oleh kaum Ibu dalam pengelolaan usaha tanaman obat keluarga melalui wawancara dengan tokoh masyarakat; (2) melakukan pelatihan pemanfaatan berbagai tanaman menjadi obat sederhana dan (3) evaluasi hasil pelatihan dan motivasi peserta pelatihan untuk mengembangkan usaha budidaya dan pengolahan tanaman obat keluarga. Hasil evaluasi menunjukkan peserta termotivasi untuk mengembangkan usaha tanaman obat. Kiat pengelolaan kebun tanaman obat secara berkelompok juga dipaparkan sehingga beban kerja individu tidak terasa berat. Secara umum, pelaksanaan kegiatan pelatihan pemanfaatan Tanaman Obat Keluarga (TOGA) cukup berhasil. Hal ini dapat dilihat dari permintaan peserta agar kegiatan ini dapat berlanjut untuk mendukung mereka. Usaha budidaya tanaman obat sesuai sebagai alternatif pemberdayaan ibu rumah tangga karena dapat dilakukan tanpa meninggalkan peran penting sebagai ibu.
\end{abstract}

Kata kunci : Ibu rumah tangga, motivasi bisnis, tanaman obat, herbal, TOGA

\begin{abstract}
The tendency of society to return to nature have increased interest in herbal remedies. This condition provides business opportunities for variety of medicinal plants including the cultivation of family medicinal plants (TOGA). The purpose of this community service activity was to increase people's motivation to exploit the business opportunity of herbal plants collectively. The program was conducted in three steps: (1) approaching the problems faced by mothers in managing medicinal plants through interviews with community leaders; (2) conducting training on the utilization of variety of crops into simple remedies and (3) evaluation of the training outcomes and motivation of training participants to develop the cultivation and processing of medicinal plants. The results showed that participants were motivated to develop medicinal plant business. Tips shared on how to manage medicinal plant gardens in groups were helpful to reduce individual workload. In general, the implementation of training activities on the utilization of Family Medicinal Plants (TOGA) was quite successful. This can be seen from the participants' request that this activity can continue to support them. Cultivation of medicinal plants is suitable as an alternative for housewife empowerment because it can be done without leaving the important role as a mother.
\end{abstract}

Keywords: housewives, business motivation, medicinal plants, herbs, TOGA

\footnotetext{
${ }^{1}$ Staf Pengajar Jurusan Agribisnis Fakultas Pertanian Universitas Riau, yeni.kusumawaty@unri.ac.id

${ }^{2}$ Staf Pengajar Jurusan Agribisnis Fakultas Pertanian Universitas Riau, shorea.khaswarina@unri.ac.id
} 


\section{PENDAhUluan}

Pembangunan kesehatan di Indonesia bertujuan mewujudkan masyarakat yang maju dan mandiri dalam suasana sejahtera lahir dan batin. Oleh karena itu gerakan meningkatkan kesehatan harus dilakukan. Menurut Desni, Wibowo dan Rosyidah (2011), pengobatan di Indonesia terdiri dari jenis pengobatan medis dan pengobatan tradisional. Pengobatan medis sering menggunakan obat, dilakukan oleh tenaga berpendidikan formal dengan metode terstandardisasi, sedangkan pengobatan tradisional dilakukan secara turun temurun.

Masyarakat meyakini bahwa pengobatan kimia lebih manjur dibanding obat tradisional. Saat ini, lebih dari 60 persen penduduk Indonesia menggunakan produk kimia untuk menunjang kesehatannya. Kenyataan di lapangan adalah penggunaan obat kimia menimbulkan efek jangka panjang yaitu banyak adanya penimbunan zat kimia yang dapat mengganggu sistem tubuh manusia seperti gagal ginjal, kanker, stroke, diabetes, obesitas dan sebagainya (Rizqa dan Kartikadarma, 2010).

Selain itu, pengobatan medis saat ini belum terjangkau sepenuhnya oleh masyarakat banyak, sehingga salah satu upaya yang dapat dilakukan untuk menunjang program kesehatan masyarakat adalah dengan mengembangkan pemanfaatan aneka tanaman obat. Pemanfaatan tanaman obat untuk menjaga kesehatan atau mencegah penyakit tergolong murah dan mudah dilaksanakan..

Menurut Kardinan dan Ruhnayat (2003), beberapa contoh obat tradisional telah diakui secara internasional dan terbukti manjur menurut penelitian. Diantaranya adalah temulawak sebagai obat hepatitis, kumis kucing sebagai penghancur batu ginjal dan daun katuk sebagai stimulator air susu ibu. Penggunaan tanaman obat sebagai obat tradisional merupakan salah satu komponen program pelayanan kesehatan dasar, serta merupakan alternatif untuk memenuhi kebutuhan dasar penduduk di bidang kesehatan. Aneka resep untuk berbagai penyakit sudah memasyarakat termasuk di Provinsi Riau.

Kegiatan menanami pekarangan dengan tanaman obat dikenal dengan toga. Program yang dahulu dikenal dengan apotek hidup ini tengah digalakkan oleh pemerintah Indonesia. Istilah toga lebih mengacu kepada penataan pekarangan. Jadi, tidak berarti tanaman yang ditanam hanya tanaman hias yang berkhasiat obat. Tanaman obat yang tergolong rempah-rempah atau bumbu dapur, tanaman pagar, tanaman buah, tanaman sayur, atau bahkan tanaman liar pun dapat ditata di pekarangan sebagai tanaman obat keluarga (Fauziah, 2007).

Keberadaan toga sangat membantu masyarakat pedesaan karena apotek, rumah sakit atau bahkan dokter belum ada atau jarang terdapat di desa. Dengan demikian toga penting untuk penyembuhan penyakit ringan serta untuk pengobatan awal bagi penderita penyakit berat sebelum dibawa ke dokter atau rumah sakit. Masyarakat di Kelurahan Sail Kecamatan Tenayan Raya Kota Pekanbaru sudah memiliki kegiatan toga. Namun kegiatan ini baru sebatas pemanfaatan untuk keperluan dapur dan penghias pekarangan.

Terkait minimnya pemanfaatan kebun toga ini perlu dilakukan pembinaan dan pemberdayaan terhadap masyarakat khususnya bagi ibu-ibu rumah tangga agar memanfaatkan toga tersebut sebagai sarana meningkatkan kesehatan keluarga sekaligus sebagai suatu usaha yang dapat meningkatkan pendapatan keluarga. Perlu dilakukan pembinaan dan pengarahan yang baik terhadap masyarakat tentang pemanfaatan toga sehingga masyarakat termotivasi untuk meningkatkan nilai tambah dari toga.

\section{8 | BULETIN UDAYANA MENGABDI}




\section{METODE PELAKSANAAN}

Kegiatan pengabdian dilakukan dengan metode pelatihan dan diskusi yang melibatkan Ibu Rumah Tangga di Kelurahan Sail Kecamatan Tenayan Raya. Kegiatan pelatihan/penyuluhan merupakan kegiatan yang dilakukan dengan tujuan untuk merubah perilaku seseorang (Saepudin, Rusmana dan Budiono, 2015), dalam hal ini untuk memotivasi ibu rumah tangga untuk memanfaatkan tanaman obat yang telah ditanam di kebun TOGA untuk pemeliharaan kesehatan keluarga.

Kegiatan dilaksanakan dalam tiga tahap, yaitu: (1) Melakukan pendekatan masalah yang dihadapi oleh kaum Ibu dalam pengelolaan usaha tanaman obat keluarga melalui wawancara dengan tokoh masyarakat (ketua RW dan ketua posyandu); (2) Melakukan pelatihan pemanfaatan berbagai tanaman menjadi obat sederhana dan (3) Evaluasi hasil pelatihan dan motivasi peserta pelatihan untuk mengembangkan usaha budidaya dan pengolahan tanaman obat keluarga.

\section{HASIL DAN PEMBAHASAN}

\subsection{Deskripsi Umum Lokasi Pengabdian}

Kelurahan Sail merupakan salah satu kelurahan yang terdapat di kecamatan Tenayan Raya, Kota Pekanbaru. Lokasi ini cukup mudah dijangkau dengan transportasi darat walaupun belum terdapat jalur angkutan umum. Angkutan yang tersedia adalah becak mesin dan ojek. Mata pencarian utama masyarakat adalah sektor informal yaitu pengrajin batu bata (80 persen), dan sisanya adalah supir, tukang dan pemilik warung.

Di wilayah ini banyak terdapat lahan tidur yang belum diolah masyarakat setempat. Umumnya masyarakat belum memperhatikan potensi yang besar di bidang pertanian, yang dapat dilihat dari keberhasilan penanaman di lahan tidur dengan tanaman buah-buahan dan umbi-umbian dengan hasil yang cukup memuaskan. Selain potensi pertanian, potensi lain adalah bidang perdagangan, karena lokasi kelurahan Sail yang terletak di tengah kota. Sebagai jalur lintasan, terbuka peluang untuk berbagai usaha perdagangan termasuk hasil olahan bidang pertanian.

\subsection{Peluang Bisnis Tanaman Obat Keluarga (TOGA)}

Saat ini masyarakat cenderung mengkonsumsi makanan dan obat alami sebagai dampak meningkatnya kesadaran akan kesehatan. Menurut Hikmat et. al. (2011), salah satu faktor penyebabnya adalah pemanfaatan obat-obat alami relatif lebih aman dibanding penggunaan obat sintetis yang banyak menyebabkan dampak negatif sebagai efek samping. Kecenderungan ini telah mendunia dengan konsep "gelombang hijau baru" atau kecenderungan "gaya hidup kembali ke alam". Kecenderungan kembali ke alam dapat dideteksi dari makin diminatinya pengobatan alternatif melalui pendayagunaan beragam tanaman berkhasiat (herbal).

Agar peranan obat tradisional, khususnya tanaman berkhasiat obat dalam pelayanan kesehatan dapat lebih ditingkatkan, perlu didorong upaya pengenalan, penelitian, pengujian dan pengembangan khasiat, serta keamanan suatu tanaman obat. Hal ini dinyatakan dalam Sistem Kesehatan Nasional (SKN), yaitu "Pengembangan obat tradisional yang ternyata telah berhasil guna dan berdaya guna serta dapat diterima oleh masyarakat". Upaya pelayanan kesehatan akan lebih lancar jika kemampuan ekonomi masyarakat berkembang, pemanfaatan obat-obatan tradisional lebih ditingkatkan, serta diadakan pengarahan dan motivasi untuk mengobati sendiri penyakit ringan dengan obat-obatan tradisional yang telah teruji khasiatnya.

Dengan mempopulerkan kembali pemanfaatan tanaman di lingkungan masyarakat sebagai tanaman obat keluarga, dapat dihasilkan pemenuhan obat dan dikembangkan sebagai sumber penghasilan 
(agribisnis). Kegiatan menanami pekarangan dengan tanaman obat dikenal dengan istilah TOGA. Menurut Hikmat et. al. (2011), pemerintah telah lama mencanangkan program Tumbuhan/Taman Obat Keluarga (TOGA), untuk menjaga kesehatan keluarga yang murah dan mandiri, namun dalam perjalanannya makin banyak dilupakan. Sehingga permasalahan ini perlu diatasi melalui suatu kegiatan revitalisasi program TOGA.

Keberadaan toga amatlah menolong masyarakat pedesaan karena apotek, rumah sakit atau bahkan dokter belum ada atau jarang terdapat di desa. Dengan demikian toga penting untuk penyembuhan penyakit ringan serta untuk pengobatan awal bagi penderita penyakit berat sebelum dibawa ke rumah sakit. Maka salah satu peluang pemanfaatan TOGA yang semakin penting adalah melalui teknologi pengolahan menjadi bahan baku obat herbal. Dengan meningkatnya kesadaran masyarakat untuk memilih alternatif obat alami, aneka jamu dan obat tradisional dari berbagai tanaman rempah semakin banyak diminati konsumen. Apalagi dengan banyaknya efek samping obat kimia, tingginya harga obat kimia dan kebutuhan masyarakat untuk menjaga kesehatan dan kebugaran tubuh, aneka tanaman fungsional semakin diperhatikan.

Walaupun memiliki peluang pasar yang cerah, olahan obat atau jamu tradisional yang harus diracik dan diseduh kurang diminati karena kurang praktis. Selain itu konsumen kurang menyukai jamu atau obat herbal yang rasanya tidak enak atau pahit. Untuk mengantisipasi keinginan konsumen ini, industri jamu mewujudkan produk minuman kesehatan yang selain menyehatkan juga praktis dan citarasanya enak. Diantara produk yang berkembang adalah industri minuman kesehatan yang memproduksi aneka minuman kesehatan instan dalam kemasan sachet seperti minuman jahe wangi.

\subsection{Potensi Bisnis Ibu Rumah Tangga}

Permasalahan yang kerap menjadi kendala untuk memulai bisnis termasuk bisnis tanaman obat (herbal) adalah kurangnya pengetahuan tentang peluang bisnis dan kurangnya motivasi dan kepercayaan diri. Maka pembinaan sumber daya manusia sangat signifikan dalam menentukan keberhasilan pengelolaan usaha tanaman obat. Menurut Pitar, Ngangi dan Baroleh (2015), sumber daya manusia adalah semua anggota masyarakat termasuk dalam kelompok usaha penanaman TOGA yang mampu dan mau meluangkan diri untuk melakukan sesuatu pekerjaan yang bermanfaat. Berdasarkan kondisi ini dibutuhkan penambahan pengetahuan melalui kegiatan pembinaan ibu rumah tangga untuk meningkatkan wawasan seputar peluang bisnis tanaman obat dan motivasi bisnis, termasuk di dalamnya jenis-jenis tanaman, cara memperoleh bibit, peluang pasar dan kiat memulai usaha dari pekarangan rumah.

Pembinaan ibu tumah tangga harus menekankan bahwa bisnis rumahan yang umumnya dilakukan ibu rumah tangga memiliki potensi sangat besar. Peran kaum wanita termasuk ibu rumah tangga dalam aktivitas bisnis merupakan hal yang tidak dapat dipandang sebelah mata. Di sela kegiatan rumah tangga, kaum ibu mampu menjalankan bisnis rumahan yang banyak diantaranya mampu berkembang besar bahkan dengan omzet jutaan bahkan miliaran rupiah. Bahkan saat ini muncul istilah "mompreneur" yang menggambarkan pesatnya bisnis ibu rumah tangga di sela aktivitas mengurus rumah tangga, suami dan anak-anaknya. Catatan IWAPI (Ikatan Wanita Pengusaha Indonesia) menyatakan lebih dari 30 ribu wanita pebisnis, tapi di lapangan dipastikan lebih banyak lagi (Rian, 2007).

Bisnis rumahan yang umumnya dilakukan ibu rumah tangga ternyata memiliki potensi sangat besar. Bisnis rumahan sebagai bagian dari Usaha Kecil Menengah (UKM) yang terus berkembang ternyata menjadi katup pengaman perekonomian Indonesia. Disinyalir terdapat sekitar 40 juta pengusaha kecil dan menengah di seluruh Indonesia, berarti 99 persen usaha adalah usaha kecil menengah, yang kebanyakan adalah pelaku bisnis rumahan. (Priandarini, 2007).

\section{0 | BULETIN UDAYANA MENGABDI}




\subsection{Hasil Kegiatan Pembinaan Ibu Rumah Tangga}

Pembinaan dan Pemberdayaan Ibu Rumah Tangga Melalui Usaha Tanaman Obat Keluarga (TOGA) di Kelurahan Sail dilakukan dalam bentuk penyampaian materi, dan diskusi. Hasil dari kegiatan menunjukkan terjadinya peningkatan pemahaman, pengetahuan, dan keterampilan ibu rumah tangga dalam bentuk kesediaan mereka untuk mengikuti rangkaian kegiatan penyuluhan mulai dari awal sampai kegiatan berakhir dengan antusias.

Hal ini terlihat dari keseriusan mereka mengikuti pertemuan serta keterlibatan dalam diskusi peluang bisnis tanaman obat Riau dan pemberdayaan perempuan melalui kegiatan bisnis tanaman obat keluarga yang dapat dilakukan dengan tidak melalaikan tanggung jawab sebagai ibu rmah tangga. serta kendala dan permasalahannya. Para ibu rumah tangga menanggapi serius materi yang diberikan dan banyak pertanyaan serta tanggapan yang diajukan terkait dengan jenis-jenis tanaman, cara memperoleh bibit, peluang pasar dan kiat memulai usaha dari pekarangan rumah.

Jumlah ibu rumah tangga Kelurahan Sail yang mengikuti kegiatan penyuluhan ini sebanyak 16 orang, kegiatan ini sebagai bentuk pendidikan non formal dapat berjalan sesuai rencana mulai dari awal sampai kegiatan berakhir. Evaluasi dilaksanakan melalui pengamatan langsung pada saat peserta mengikuti penyampaian materi dan diskusi. Sebagian besar peserta antusias disebabkan materi yang diberikan sesuai dengan kebutuhan dan merupakan hal baru dan menjadi alternatif memperoleh pendapatan tambahan.

Evaluasi juga dilakukan pada akhir kegiatan terhadap berbagai aspek, seperti materi, praktek, metode penyampaian maupun waktu. Hasil evaluasi menunjukkan mayoritas ibu rumah tangga menganggap kegiatan pembinaan merupakan materi yang sangat bermanfaat bagi mereka, dan antusiasme tampak meningkat dengan penyajian slide berwarna tentang ragam tanaman obat.

Hasil evaluasi menunjukkan peserta menjadi termotivasi untuk mengembangkan usaha tanaman obat yang dimulai di pekarangan rumah dengan jenis yang sesuai iklim setempat. Selama ini ibu rumah tangga umumnya telah memiliki koleksi tanaman obat seperti rosella dan lidah buaya, tetapi belum memandangnya sebagai potensi penghasilan keluarga. Kiat pengelolaan kebun tanaman obat secara berkelompok juga dipaparkan sehingga beban kerja individu tidak terasa berat dan dapat dilakukan di sela tugas-tugas rumah tangga. Lahan sisa atau lahan terbengkalai dengan ukuran terbatas pun dapat dimanfaatkan untuk pengembangan kebun TOGA. Hal ini sesuai dengan kajian Latif (2010), bahwa pengembangan TOGA dianggap sebagai solusi baru yang minim biaya, memenuhi asas aksesibilitas kesehatan dengan jalan pemanfaatan lahan rumah dan meskipun hanya lahan sisa dapat dimanfaatkan secara optimal.

Secara umum, pelaksanaan kegiatan Pembinaan dan Pemberdayaan Ibu Rumah Tangga Melalui Usaha Tanaman Obat Keluarga (TOGA) di Kelurahan Sail Kecamatan Tenayan Raya Kota Pekanbaru dikatakan berhasil. Hal ini dapat dilihat dari permintaan peserta agar kegiatan ini dapat berlanjut sehingga usaha yang akan mereka lakukan dapat berjalan dan terlaksana sesuai harapan. Peserta sangat berminat dengan adanya peluang usaha di daerah Subang Jawa Barat yang bersedia menampung tanaman obat khsusunya jenis rimpang, sekaligus menerima hasil olahan berupa minuman herbal berkhasiat jika masyarakat mampu mengembangkannya. 


\section{KESIMPULAN DAN SARAN}

\subsection{Kesimpulan}

1. Ibu rumah tangga yang mengikuti kegiatan penyampaian materi berjumlah 16 orang dapat memahami materi penyuluhan dan mengambil manfaat dari hasil kegiatan.

2. Setelah penyuluhan ibu rumah tangga Kelurahan Sail memiliki wawasan tentang jenis tanaman obat yang cocok untuk dikembangkan dan termotivasi untuk mencoba usaha bisnis tanaman obat skala rumah tangga.

3. Keterlibatan peserta dalam pembinaan relatif tinggi ditandai dengan banyaknya pertanyaan dan diskusi yang berkembang dari hal-hal baru yang mereka terima serta suasana diskusi yang hangat.

\subsection{Saran}

1. Peran Aparat desa dalam sosialisasi dan penerapan usaha tanaman obat secara kelompok melalui dukungan sarana dan prasarana penunjang bagi masyarakat termasuk kaum ibu rumah tangga.

2. Perlu pembinaan dari semua instansi dan aparat terkait baik pemerintah, swasta maupun perguruan tinggi yang berkelanjutan agar usaha tanaman obat skala rumah tangga dapat berkembang dan menjadi alternatif upaya pengentasan kemiskinan dan pembukaan lapangan kerja pedesaan.

\section{DAFTAR PUSTAKA}

Desni, F., T.A Wibowo dan Rosyidah. (2011). Hubungan Pengetahuan, Sikap, Perilaku Kepala Keluarga dengan Pengambilan Keputusan Pengobatan Tradisional di Desa Rambah Tengah Hilir Kecamatan Rambah Kabupaten Rokan Hulu, Riau. Jurnal KESMAS 5(3): 162-232

Fauziah, Muhlisah. (2007). Tanaman Obat Keluarga. Penebar Swadaya. Jakarta

Hikmat, A., E. A.M. Zuhud, Siswoyo, E. Sandra, dan R. K. Sari. (2011). Revitalisasi Konservasi Tumbuhan Obat Keluarga (TOGA) guna Meningkatkan Kesehatan dan Ekonomi Keluarga Mandiri di Desa Contoh Lingkar Kampus IPB Darmaga Bogor. Jurnal llmu Pertanian Indonesia Agustus 2011:71-80

Kardinan, Agus dan Ruhnayat, Agus. (2003). Budi Daya Tanaman Obat Secara Organik. PT. Agro Media. Jakarta

Latif, R.V.N. (2010). Pemanfaatan Lahan Rumah untuk Tanaman Obat Keluarga (TOGA), Sebagai Bentuk Upaya Promosi Kesehatan Masyarakat pada Level Keluarga. Biofarm Jurnal Ilmiah Pertanian Vol XIII (9): 64-72.

Pitar, F., C. R. Ngangi dan J. Baroleh. (2015). Peran Sumber Daya Manusia dalam Kelompok Tani Tanaman Hias Gapoktan TOGA Kelurahan Mahakeret Barat. Jurnal COCOS 6(3):1-11

Priandarini, L. (2007). Panduan Lengkap Memulai dan Mengelola Usaha di Rumah. Transmedia Pustaka Jakarta.

Rian. S. (2007). Bisnis di Bawah Telapak Kaki Ibu Rumah Tangga. Majalah Pengusaha Edisi 69/Februari 2007. hal. 9.

\section{2 | BULETIN UDAYANA MENGABDI}


Rizqa, I., dan E. Kartikadarma. (2010). Perangkat Lunak Penyusunan Formula Herbal sebagai Media Pelestarian Budaya Pengobatan Tradisional Khas Indonesia. Prosiding Seminar Nasional Sains dan Teknologi: 28-33. Fakultas Teknik Universitas Wahid Hasyim Semarang.

Saepudin, E., A. Rusmana, dan A. Budiono. (2015). Model Manajemen Pengetahuan Sebagai Bentuk Diseminasi Informasi Tanaman Obat Herbal dan Tanaman Obat Keluarga (Studi Kasus di Desa Cisondari Kecamatan Pasirjambu Kabupaten Bandung). Sosiohumaniora 17(2): $100-106$ 